\title{
María Luisa Pardo Rodríguez (COORD.), Iglesia Y Escritura en Castilla. Siglos XII - XVII, SeVIlla, Editorial Universidad de SeVILla, 2019, 342 PÁGS. ISBN: 978-84-472-2887-4.
}

\author{
Maria João Oliveira e Silva \\ CITCEM \\ Universidade do Porto
}

O livro em epígrafe, e como salientado logo no Prólogo do mesmo (pp. 9-11), é uma das faces visíveis do trabalho efetuado por uma equipa de investigadores vinculados ao projeto de I+D+I (HAR2013-41378-P) intitulado Iglesia y Escritura en Castilla (siglos $X I I-X V I I)$, a que se associaram outros especialistas europeus no sentido de enriquecer, através da comparação, o estudo do tema central do projeto. A publicação conta, por essa razão, com um total de 12 artigos de autores provenientes de várias universidades espanholas, mas também de Portugal e de Itália, o que resulta na enriquecida produção de textos escritos em três línguas diferentes. Mas esta diversidade funde-se no objetivo comum de estudar o binómio Igreja-Escrita nas suas mais variadas facetas e cronologias e procurando sempre visões interdisciplinares. Nesse sentido, os estudos efetuados resultam de abordagens que privilegiam os estudos de Paleografia, de Diplomática, de Codicologia e de Arquivística sempre com o "pano de fundo" da História.

Em relação aos estudos que dão especial enfoque à análise paleográfica devem referir-se os de Adrián Ares Legaspi (La introducción de la escritura humanistica en la Iglesia de Santiago de Compostela: fechas, protagonistas y caracteristicas, pp. 13-43), Carmen del Camino Martínez (Un libro de notas de los escribanos de la indulgencia (Sevilla, 1445), pp. 105-136), $\mathrm{M}^{\mathrm{a}}$ Isabel González Ferrín (Un mandato en papel de Alfonso X en el Archivo de la Catedral de Sevilla, pp. 209-240) e M ${ }^{a}$ Luisa Pardo Rodríguez (Escribir para la Iglesia. El notario Alfonso González de Tarifa, contador de Sevilla (1453?-1483), pp. 277-305). No entanto, refira-se que estes artigos incluem também, em larga escala, análises diplomáticas, codicológicas e históricas que lhes conferem ainda mais qualidade.

Por seu lado, poder-se-ão agrupar no conjunto de artigos particularmente centrados em estudos de Diplomática os de Diego Belmonte Fernández (Un obituario sevillano del siglo XIV: el Curso de los Aniversarios, pp. 45-63), María Antonia Carmona Ruiz (Conflictos antiseñoriales en los dominios de la orden de Calatrava. La memoria escrita de los abusos de los comendadores de Torres y Jimena (Jaén) a finales del siglo XV, pp. 65- 
92), Maria Cristina Cunha (Do scriba monástico ao publicus tabellio: algumas reflexões a propósito de um caso português, pp. 93-103), Antonio Claret García Martínez (1633, la memoria reconstruida. Estrategias de escritura y proyección social de Bernardino de Obregón en su proceso de beatificación, pp. 137-157), María Luisa García Valverde (Los notários-secretarios de la Catedral de Granada: 1496-1550, pp. 159-187) e Javier E. Jiménez López de Eguileta (Los estatutos medievales del cabildo colegial de Jerez de la Frontera (1484), pp. 241-275). De salientar que estes trabalhos comportam, não raras vezes, investigação de carácter paleográfica, codicológica, arquivística e histórica.

Num terceiro grupo é possível incluir dois estudos especialmente focados em análises de códices e de scriptoria, nomeadamente os de Nicoletta Giovè Marchioli (Modalità di produzione e di fruizione del codice francescano, pp. 189-208) e Elena E. Rodríguez Díaz (El monasterio de Guadalupe y su actividad de copia de libros en el siglo XV (BNE, MSS 10156 y 4127), pp. 307-318). Novamente se destaca que questões paleográficas, arquivísticas e históricas também estão presentes nestes trabalhos.

A esta multiplicidade de abordagens deve juntar-se a multiplicidade de fundos e fontes documentais que serviram de base a estes estudos. Com efeito, desde documentação avulsa (de natureza jurídica diversa) passando por códices diplomáticos, administrativos ou de outra natureza, e tanto de origem episcopal, como capitular, monástica, religioso-militar, régia ou notarial. Os "protagonistas", muito concretamente os autores materiais, são também muitos e variados, sendo se salientar a presença dos notários apostólicos, dos escrivães capitulares e dos escribas monásticos, assim como de todo um conjunto de oficiais ligados a diferentes oficinas de produção documental. Também de sublinhar a variedade de geografias presentes nos artigos, e que remetem para vários pontos da Península Ibérica e também de Itália. As cronologias são igualmente diversificadas e estendem-se desde os finais do século XII até à primeira metade do século XVII.

De forma a enriquecer ainda mais vários dos artigos presentes neste volume foram acrescentadas imagens ilustrativas de muito boa qualidade. Dois deles incluem, também, apêndice documental. E de modo a reunir toda a bibliografia e webgrafia citada pelos autores, foi acrescentada uma Bibliografía geral no final da obra (pp. 319-342).

É possível olhar para este livro como um puzzle que junta peças de formato diverso, mas que, no seu conjunto, permite ao leitor obter uma imagem muito interessante da relação entre a Igreja e a Escrita em especial (mas não exclusivamente) em Castela, no período entre os séculos XII e XVII. E esta relação é vista, como referido, de vários ângulos e de várias perspetivas. Mas talvez a grande mais valia desta obra seja a de demostrar claramente a importância dos estudos nas áreas da Paleografia, da Diplomática, da Codicologia e da Arquivística para a História e, muito concretamente, para a História da Igreja. Ao leitor só resta desejar que projetos como o que deu origem a este livro se venham a multiplicar para que mais frutos venham a ser colhidos. 